\title{
Perception of Growth Condition in the University from the Perspective of Freshmen Students
}

\author{
Ana Paula Moreno Pinho*, Antônio Virgílio Bittencourt Bastos, \\ Angra Valesca Almeida de Jesus, Rebeca Aurélio Martins, Laís Carvalho Dourado \\ Institute of Psychology, Federal University of Bahia, Salvador, Brazil \\ Email: *anamorenopinho@gmail.com, ${ }^{*}$ anabrito@ufba.br, virgilio@ufba.br, angravalesca@hotmail.com, \\ rebecaurelio@gmail.com, lai cdourado@hotmail.com
}

Received 16 January 2015; accepted 4 February 2015; published 10 February 2015

Copyright @ 2015 by authors and Scientific Research Publishing Inc.

This work is licensed under the Creative Commons Attribution International License (CC BY).

http://creativecommons.org/licenses/by/4.0/

c) (i) Open Access

\section{Abstract}

This study aims to analyze and assess the perceptions that freshmen students recent graduating from high school have towards their adaptation in college, as well as comprehending how this process of transition from high school to college occurs. Thus, a qualitative study was conducted, using semi-structured interviews. Eight students from a public college institution in Brazil participated in this study. Analysis of Content was used in order to analyze the data, which were grouped into semantic categories. The results show that the aspects related to teaching, didacticism and relationship with professors are important to the adaptation process and these three aspects are from interdependent categories. Although the insertion in a different environment was potentially adverse, the students cope this reality as an opportunity for personal growth. Regarding to the perception of the growth condition, the results show that the participants focused in extracurricular and curricular activities offered by the University and not in the affirmative policies.

\section{Keywords}

Academic Transition, College Life, Growth Condition, High School

\section{Introduction}

A significant growth of the number of students getting into college is being perceived in several universities

*Corresponding author.

How to cite this paper: Pinho, A. P. M., Bastos, A. V. B., de Jesus, A. V. A., Martins, R. A., \& Dourado, L. C. (2015). Perception of Growth Condition in the University from the Perspective of Freshmen Students. Creative Education, 6, 154-163. 
throughout the world (Teixeira, Castro, \& Piccolo, 2007; Almeida \& Cruz, 2010). In Brazil, the expansion of higher education has been a reality and it is a result of policies that are being developed in the country. For example, basing upon data from the Brazilian Ministry of Education, Machado (2009) reports that in just six years (2003 to 2009) the number of admissions to college would go from 113 thousand to 227 thousand. Besides this, there are two other programs that have helped with the growth of the number of admission, known by Program for Restructuring and Expansion Support, and University for All People has offered thousands of full-tuition scholarships in private schools.

At the same time, the number of studies about academic failure due to low grades, absenteeism, changes of courses and dropping out are increasing (Almeida, Soares, \& Ferreira, 2000; Igue, Bariani, \& Milanesi, 2008). Therefore, the first academic year in college has been pointed in the perusal as a critical period to define the permanence of the students in college, because it involves a process of transition and adaptation to a completely different reality from what is observed in high school (Almeida, 2002; Almeida, Soares, Guisande, \& Paisana, 2007).

The academic transition occurs when the presence or the absenteeism of certain event results in changes in the routine, in personal and social life, as well as changes in the social role the individual plays, which may affect the way a person perceives themselves and the world. Getting into college is an unique process of transition, for it coincides with developmental changes that belong to the transition from youth to adulthood (Teixeira et al., 2008).

Otherwise, the professional choice seems to be in the background for the sheer fact that after getting admitted for a post-secondary institution, the young adult perceives himself as a college student (Teixeira et al., 2008). Getting into college, therefore, brings an impact beyond professionalization, for, to many people, this new context brings the needs to, for the first time, perceive themselves in a reflective social status, establishing personal goals, critically analyzing their abilities and skills, performance and social background.

The insertion in the university context will result, necessarily, in a change in the social and friendship circle, and, for some people, there maybe even the needs to move to other places or cities to attend college (Teixeira, Castro, \& Piccolo, 2007). Almeida and Cruz (2010) single out that freshmen students have to deal with an unknown context and, sometimes, this new context may be slightly integrative. With this, the student has to manage, more autonomously, their financial expenses, time for studying, career and the time spent with friends (Almeida, 2007; Ferreira, Almeida, \& Soares, 2001; Soares, 2003; Taveira, 2002). In this way, the majority of the difficulties of the process of transition and academic adaptation are related to the fact that the students in their first year of college have to use cognitive efforts to cope with the situations presented by the new academic context.

Those students who can perform an academic and social integration in the first few semesters of the course, probably will find it easier to grow personally and intellectually, and seize with efficacy the opportunities offered by the university. Impasses faced by students can be constituted as a catalyst for the development of coping strategies and problem-solving skills that will be useful not only for the years of graduation but also for the professional environment in the future (Teixeira et al., 2008).

Thus, this study aims to assess the transition experienced by the student when leaving high school to get into college, as well as analyzing the meaning of being a college student. To achieve the overall objective, the following specific objectives were set:

- Analyze high school and university contexts;

- Identify the differences between high school and college;

- Analyze the impact of the differences between high school and university towards the student's adaptation;

- Identify and analyze growth conditions in the university in the perspective of the student that just graduated from high school.

Public higher education in Brazil and in the state of Bahia has passed through an expansion in the last five years, which has resulted in continued growth of admissions, number of majors, new teaching units and the implementation of affirmative policies in this context. Facing the changes in post-secondary schools in Brazil, a study is crucial to understand the phenomenon presented. Considering this, this paper seeks to fill a gap in the literature, for there is still lack of studies that aim to analyze this current reality of higher education, as well as the conditions of new students, being them university entrants recent graduated from high school.

Thus, this paper contributes to understanding this process by providing data that demonstrates how the process of adapting to the college environment has occurred, especially in the Brazilian context, as well as con- 
tributing to identifying what are the obstacles faced towards achieving a successful transition between high school and university considering the changes related to the developmental age of the students. This study also seeks to provide information to the development of policies that can be implemented by the academic institutions, aiming to give more support to freshmen students and their psychosocial well-being.

\section{Method}

The study was conducted from a qualitative method of collecting and analyzing data since this method is valid to understand the phenomenon studied. Thus, the subjects involved had the opportunity to report characteristics of their personal experience to the topic discussed.

\subsection{Instrument}

An interview was conducted in this research and its content are based upon the Experience and Academic Transition Questionnaire (QETA) developed in Portugal by Azevedo and Faria (2003), which consists of 28 items that are distributed in five dimensions-Teachers, Family, Social Relation, Course Organization, Syllabus. Thus, 12 questions were developed based on these dimensions proposed by QETA to meet the objectives pursued in this investigation.

The questions aimed to: 1) investigate the process of transition and adaptation by questioning the expectations upon college; 2) analyze the first impressions perceived after enrolling at the university; 3) collect data about the factors that facilitated or interfered the adaptation; 4) study perceived differences between the realities of high school and university; 5) point out the perception of growth conditions offered by the university; 6) identify possible personal changes, elapsed when getting into university, and 7) verify the expectations for the following years of graduation.

In this article we will explore the contents obtained with the questions which emphasized the factors related to the transition and adaptation process and also the growing conditions from the perspective of incoming students.

\subsection{Participants}

The study included a total of eight people between 18 and 23 years old from different majors (Dentistry, Social Sciences, History, Nursing, Executive Secretary, Economic Sciences, Chemical Engineering and Design) attending the initial semesters of their respective courses at a federal public institution of education. The students graduated from both public and private high schools -5 females and 3 males. We sought the widest possible variety of courses because it was assumed that these courses offer different realities within the university both in terms of infrastructure units as the specificities of the course and its organization.

\subsection{Data Collection}

The interviews were conducted in units of the university, where students were approached and asked about what semester they were attending and the gap time in between graduating from high school and getting into college. The subjects of the study were those who agreed to participate, who were attending the initial semesters of their respective courses and who entered the university in a relatively short time after completing high school. Students that did not get into college at least until twelve months after graduating from high school were not able to be considered in the sample, for longer time in between graduating and getting into college might influence the transition and the way students cope the obstacles, since they are older and might have passed through other activities as getting a job or taking other courses. Individual interviews were held in a single session that lasted on average 20 minutes. After the consent of the participants, the interviews were recorded and later transcribed and grouped into semantic categories. Data were grouped into categories and subcategories defined from the participants' speech and divided into two large blocks of analysis defined in this research objectives.

The content analysis technique was used with the data obtained in this study. This technique aims the study and analysis of the communication in an objective, systematic and quantitative way, says Martins (2006). The information about the questions that guide this research problem were singled out as they would appear in the speeches of the students. The author mentioned above approaches that the essence is emphasized in the context of details of the information available, focusing not only on the text, but mainly on the way the word is used. Therefore, the content analysis is not restricted to the description of the contents revealed in the interview, but on the total showed in the communication, seeking to understand about the causes and backgrounds of the mes- 
sage, as well as the effects reported by the interviewees.

The authors Dellagnelo and Silva (2005) and Martin (2006) showed, in a similar form, three stages or times of content analysis. Initially, the pre-analysis, which corresponds to collecting, organizing the material and defining the procedures to be followed. Then, there is the material exploration phase, involving the analytical description, with the implementation of procedures: counting words or other units of analysis, survey categories already tested or construction of categories from the frequencies and common meanings of the units of analysis. The categorization includes the inventory of units of words' analysis, themes, phrases and the classification of common units revealing the categories. The third step constitutes of the processing of data, which involves generating inferences and interpretations about the text in general.

\section{Results}

The data presented below correspond to the two large blocks of predefined analysis for this study: High School versus University and Growth Conditions. The answers of the respondents were grouped into semantic categories and then into subcategories, since the same general theme was approached from different perspectives.

The first block of analysis and discussion, High School versus University, is related to any comparison, reported by the interviewees, between their experience in college and in high school. The purpose of this was to map the main differences and/or similarities perceived between these two realities. Six categories were defined for this block, presented below in Table 1.

It is possible to observe that the category that had more quantity of content and mentions (14) is University Context and the second category is Content, with 7 mentions.

The second block of analysis and discussion, Growth Conditions, is related to the opportunities students perceived as conditions for growth offered by the university. Table 2 shows all the categories and subcategories and the answers related to them, as mentioned by the participants in the research.

Table 1. Differences in between high school and university.

\begin{tabular}{cccc}
\hline \multicolumn{1}{l}{ High School versus University } & & \\
\multicolumn{1}{c}{ Categories } & Subcategories & Frequency (by Subcategory) & Total Frequency (by Category) \\
\hline \multirow{2}{*}{ University Context } & Autonomy & 4 & 14 \\
& Demand & 3 & \\
& Insertion on a Heterogeneous Social Environment & 4 & 7 \\
Content & Workload & 3 & 6 \\
\hline Didacticism & Objective & 4 & \\
\hline \multirow{2}{*}{ Relation Professor - } & Reflective & 3 & 5 \\
Student & Different Teaching Methods & 6 & 1 \\
\hline Activities Offered & Affective Bonding & 1 & 1 \\
\hline Psychal Structure & Relation of Authority & 2 & 2 \\
\hline
\end{tabular}

Elaborated by the authors.

Table 2. Summary of the affirmative policies and opportunities offered.

\begin{tabular}{cccc}
\hline Growth Conditions & & & \\
\hline Category & Subcategory & Frequency (by Subcategory) & Total Frequency (by Category) \\
\hline \multirow{2}{*}{ Affirmative policies } & Knowledge about the Offers & 1 & 2 \\
\hline \multirow{5}{*}{ Opportunities } & Perceived Failure & 1 & 4 \\
& Extracurricular & 4 & 12 \\
& Belonging to the Syllabus & 1 & 1 \\
& Personal Growth & 2 & \\
\hline
\end{tabular}

Elaborated by the authors. 


\section{Discussion}

\subsection{High School versus University}

\subsubsection{University Context}

The first category, University Context, was created from the answers that indicate particular characteristics about the university environment. In general, all the speeches of the participants regard to this issue pointed to the effects of the university context on personal studies and on their personal lives. Among the subcategories, we have: Autonomy, Demand, Insertion on a Heterogeneous Social Environment and Workload.

The subcategory Autonomy is directly associated with the structure of the university in comparison to high school. Students report that, in the university, there is less regulation related to teaching and learning process, that is, being loose and having weak norms for behavior; the university was reported also as an institution that directs the responsibility for learning to the individual rather than the institution, as it is perceived for the high school context. The university, therefore, represents a rupture with the model seen in the secondary education, an issue pointed by Texeira et al. (2008): the interest in monitoring decrease at the university, so that the responsibility for learning, which previously belonged to the school, is now expected to be managed by the college student.

Soares Almeida Diniz and Guisande (2006) highlight that the student is responsible for their own autonomy in the learning process and in the organization of their time and methods of study, remarked by a participant: “(...) in college you are very free to do what you want. Nobody reminds you to study. You are the one who sets your goals and demands.”

In a way, this change is perceived positively, as they realize themselves with autonomy, possibility of growth and of establishing their own rules and choices. At the same time, freshmen students seem to face more pressure about having to take care of themselves, to take responsibility. This, therefore, usually represents a source of anxiety.

The content related to the category Demand is related to the level of difficulty that the university offers. This aspect is strongly related to the academic domain, defined by Almeida and Soares (2000), which relates to the imposition of new rhythms and learning strategies due to changes in the ways of teaching and assessment. And also it highlights the need for new students to adapt to the new system of teaching and assessment, which requires higher levels of cognitive efforts and abilities (Soares, Poubel, \& Mello, 2009).

Some respondents confirmed that the university seems more demanding and harder than high school, especially when related to the quantity of subjects to study and to the exams and tests. This difference influences on how the student deals with studies and time, since this change requires an adaptation to the demand and more time dedicated to academic aspects.

The subcategory Insertion in a Heterogeneous Social Environment is related to the meaning of entering into an institution with a substantial structure, both physically and diversity. Teixeira et al. (2008) point that the majority of freshmen students describe high school as the place where they would spend most part of their time, where their life would get organized and where they had most part of their friends. Given this, it is comprehensible that the university context presents itself so differently from secondary education, which was pointed as a strict and limited environment.

While for some people getting into a new place seems challenging, for other people this change can be coped as an opportunity to broad their perception of the world and personal growth. Regarding this aspect, a participant reports: “(...) [the university] helped me, you know... to get out of a little box I was in... it helped me to know other things”.

The subcategory Workload is about the organization of the class prepared by the majors in the university in comparison to high school. It was noticed that students have a perception that the university consumes much more time, demanding that they reorganize their studies, their inclusion in extra-academic activities and their personal life.

\subsubsection{Content}

The second category, Content, gathers contents that highlight the perception of the students in reference to the type of the content learned and how it is passed to the students in high school and in college. Thus, from this category, two subcategories are given: Objective and Reflexive.

The subcategory Objective refers to the type of knowledge and its transmission in high school compared to 
college. Students understand that the main goal of the secondary education is to convey the contents, that were set by the institution, get good grades and pass the year without necessarily worrying about the personal human development.

Closely linked to the subcategory mentioned above is the subcategory Reflective, remarked, including, by the same person in addition to the information already reported in the interview. In this category, however, the focus of the speeches is on the perception that students have about the content of university education. Unlike high school, the content to be learned in college requires the student a higher level of reflection, and even encourages the student to think for himself and make questions, creating a space for the student to form and share and respect critical opinions.

In this sense, Almeida and Cruz (2010) corroborate this perception of students as they consider the teaching and learning environment at the university a very different reality of the one encountered in secondary school. Besides the fact that the university is considered an environment where there is not a strict standard of rules dictating the pace of discipline and classes, as in high school, there is more interest in developing skills in college students.

At the same time, it was noticed that the learning process at university goes beyond its environment since it focus on professional and personal development (Coulon, 2008). The education thus comes to incorporate a meaning for the students, as they begin to observe that this is a necessary knowledge for life, for their professional future, much more observed in college than in high school, where the knowledge is more objective.

\subsubsection{Didacticism}

The way the content is transmitted to the students is directly related to the content itself-a practical content is likely taught in a practical way, and an objective subject is likely taught in objective ways. Therefore, the Didacticism category approaches those contents which make reference to the comparison between the way knowledge is conveyed by instructors in high school and university. The students tend to value the degrees accomplished by their professors, and consider this aspect a moderating factor that affects the quality of the teaching. The amount of years of education of high school teachers in comparison to the university professors seems to reflect the perception of students regarding the attitudes of professionals in the classroom and the quality of teaching in both contexts. This student says:

In high school the teacher is there, not very much committed. We even notice that the school does not have an adequate teaching. But is not like that in the university. Because it is a federal university, its name is known. We have masters and PhD's professors [...]. But in high school we don't have anything like that.

Another student, on another hand, provides different information, reporting how demanding high school was for his graduation:

[...] everything was very different because in high school everything is more tiring for the student, it is stressful, and at least in the period that I was studying in secondary education and in high school I had wanted everything to go away as fast as possible. I wanted to get rid of it and get done with my studies.

The complaints towards the didacticism can be strongly associated with the characteristics mentioned above, that the knowledge transmitted in high school is much more objective, with little proximity with reality, strict and strongly requires memorizing subjects for the exams rather than learning and practicing (Almeida \& Cruz, 2010).

\subsubsection{Relation Professor-Student}

The fourth category Relation Professor - Student covers the relationship between professor and student in secondary and postsecondary education. Three subcategories were created: Affective Bonding, Relation of Authority and Relation of Independence.

Affective Bonding refers to the distance or the proximity in the relations in between professor and student, compared to high school. At the university is possible to notice, from the answers of the students, that the relationships look much more resistant. A student says: "I think you do not have a strong relationship with your professors and your colleagues. It is much more difficult to make friends".

The high school environment seems to help with affective bonding, both with the peers and with the teachers, for there is a possibility of having the same colleagues around for years; regarding to the teachers in high school, 
they are used to teach to the same group of students for at least a year, and they see the students regularly during the week. This fact can help understand why the student above mentioned that is harder to make friends and have bonds with the professors while at university, since classes are different each semester, the students usually take different classes during the graduation and there is heterogeneity of personalities grouped in the same class.

In fact, Teixeira et al. (2008) point out that certain authors (Diniz \& Almeida, 2006; Pascarella \& Terenzini, 2005) highlight being vital a satisfactory social integration in the new context for a better adjustment to university. Given this, it is important to consider that relational issues appear as influencers on the students' adaptation to the university.

The Relation of Authority was perceived only in high school, since the respondents reported that this environment strongly reinforce the role of the teacher as a hierarchical authority holder before the students. Certain participant pointed out: "the issue of the teacher with the student: the teacher always knows you're only there to learn what he says and period... That thing, the teacher talks and the students have to obey, that punitive thing”.

It is observed that this category is directly related to the previously analyzed on the objective and reflexive contents. For, the knowledge that is needed to be taught influences the way it is going to be conveyed to the students. The fact of conveying a knowledge that is objective, is strongly connected with the idea that the teacher has knowledge, that he is in charge to teach and the students are in charge to learn; the relationship is well defined and marked, being designated that the student has the passive role of obedience and expectador.

In contrast to this, the knowledge learned at university, having more reflective aspects, often involves the participation of the students, demanding that they opine and reflect on what is said. Also, that way, the students are more likely to increase their academic goals and their knowledge during graduation, thus altering its relationship with the studies, consequently, with the professor who also helps with information and advices to students achieve their goals.

The Relation of Independence brings another perspective about the relationship student-professor. For the participants that mentioned this content, the teacher in high school is seen as a professional that possess a directive role, assisting students more closely, what generates a relevant reliance on students to their instructors; this perception is associated with the idea that the teacher assumes a motherly/fatherly role, and that they usually facilitate to the student. One participant points out this issue as follows:

For example, when we're in high school [there is a need for the teacher to] help you, [...], is like a father and a mother, but not here, where is totally different. The [university] makes you seek more things by yourself, it's totally different.

It is noteworthy that this perspective was brought by students that attended their secondary school at a private school. About the university, the professors assume another role in the relationship, acting more as facilitators, promoting independence and enabling the student to experience more autonomy.

\subsubsection{Activities Offered}

The category Activities offered refers to the diversity of activities that can be developed and offered by the university, compared to those offered in high school. For the students, high school has limited opportunities, which restricts the potential of the students; On the other hand, the possibility of engaging in diversified projects during their college graduation is viewed positively since it contributes to the perception of adjustment and professional growth for the participants.

\subsubsection{Physical Structure}

The category Physical Structure refers to a comparison of the psychical space in the university and the school contexts. One student, from a public school, ponders that the physical space in a school is becoming less welcoming, and, somehow, even repulsive; this contrasts with their perception of the university, ample space that is open and accessible even in times when there is not class to attend. The student has the opportunity to attend university even in their free time, which allows them a better use of this space (library, computer lab etc).

\subsection{Growth Conditions}

This topic was elaborated in order to identify in the answers of the students what is seen as a growth opportunity offered by the university. Two categories were configured: Affirmative Policies and Opportunities. 
It is important to mention the lack of studies regarding the influence of growth condition offered by universities, what is possibly related to the recent federal affirmative policies implementation in the Brazilian educational system.

\subsubsection{Affirmative Policies}

The category Affirmative Policies was defined from two opposite categories, one refers to the Knowledge about the Offers and the other one about Perceived Failure. Two people mentioned this category, and it is divided in terms of offering affirmative policies or lack of this offering. The student reports that he does not know about offers of affirmative policies. He says:

I felt difficulty because we don't have, for example, financial aid, and if we have nobody has informed me. We don't have support on printing out papers, and other institutions do. I didn't know we didn't have this support, then I felt difficulty about it.

It is important to mention, though, that although the student does not know about the affirmative policies, it does not mean that these do not exist. On another hand, may indicate the need for greater disclosure and dissemination of this information by the university.

\subsubsection{Opportunities}

The aim of the category Opportunities was to gather all the answers that demonstrates what type of policies are perceived as growth conditions by the college students. The answers approach five subcategories: Extracurricular, Belonging to the Syllabus, Professional Network, Personal Growth and Limited.

The Extracurricular subcategory covers the answers that are related to complementary activities offered by the institution. These activities are not mandatory, and are perceived as important in order for the student to develop skills and abilities for their own professional growth on a specific field. Among those cited, there are: opportunities of studying abroad, Science without Borders program, scholarships for scientific research and extension projects.

In this sense, the literature has pointed out the importance of extracurricular activities to integrate the student into the university environment. For, as Teixeira et al. (2008) remark, non-mandatory academic activities enable contact with other professors and students, moreover, more time dedicated to these activities encourages academic involvement and responsibility for an activity that was chosen optionally.

The subcategory Belonging to the Syllabus covers the answers that mention, specially, material and theoretical material, offered mandatorily by the post-secondary education institution. Theoretical resources are the knowledge and are the basis for professional practices, as it is shown as follows: "The theory that is being applied sometimes is not even from my course, but they put the class in the Syllabus so that it can help the students understand the society and how I should act as a professional”.

Material resources are the equipment that the university provides in order for the student to experience practical contents required for the graduation. It is noteworthy that the student who mentioned this issue studies Chemical Engineer, and, for this course, the materials are indispensable for the acquisition of knowledge required in professional practice. The student who addressed this issue says: "All the equipment we need-because Chemical Engineer requires the usage of computer, simulation, several programs for several types of substances—-we have: several computer labs already with the programs installed”.

Another subcategory mentioned by one participant is related to the Personal Growth. The person answered that even when the resources offered by the university are flawed, the fact of having to adapt themselves in order to find a creative alternative helps the students grow as a person, enabling them to handle adverse situations.

Thus, these data corroborate the results found by Pachane (2003), which shows that students excel the expectations about the university - they usually expect to seek in the university professional training, qualification and achievement as well as personal growth. Thus, the student expects of the university all the support, preparation and professionalization and opportunity to grow as persons.

In the subcategory Professional Network was allocated the content remarked by a student who singles out the university as an environment useful for future employment contacts, because there is the possibility to know and to contact references in the area that, somehow, can contribute and facilitate the student's insertion in work organization. This aspect is evidenced in the following statement: "The network provided by the university is very important for contributing for future opportunities in your field of study.” 
The Limited subcategory refers to the image students have that the university has gaps in some aspects that would contribute to the growth of the student. An interviewee points out the need to seek extracurricular courses to fill the gaps imposed by the lack of structure of the university may hinder the student's growth and learning. A student says: "For lack of structure means lack of access, this access is our right and lacking of access inhibits our learning process, forcing us to take extra courses, for example”.

For another participant, the university should promote more integration with the surrounding environment, with outdoor classes. This issue is shown as follows:

"As here is a historic place (...), we could explore this place to have class, get outdoors, and have a closer contact to people. We should step out a bit of academic subjects, or of the restriction of having to read textbook, papers. I think we should go to outdoor places more often.”

The data analyzed show that, for the participants, the aspects between high school and university with more relevance are associated to the changes in context, that reflect on personal issues such as autonomy and as the way the world is perceived. Also, it is possible to observe that the results show as important the aspects associated with the type of knowledge disseminated in both contexts and how they are transmitted, and in comparison to the contexts the answers attribute to university a better status then in high school.

Otherwise, regarding to the growth condition, it can be observed that the students barely mentioned the affirmative policies in the university context, being more highlighted the aspects related to curricular and extracurricular activities offered by the institution. This may indicate a lack of knowledge about the existence of aid and resource offered to the students, probably due to failures in the process of informing the students.

From the description and analysis of the data, we can conclude that the most relevant aspects in comparison between high school and university are regarding the University Context (14) Content (7) Didacticism (6) and Relation Professor - Student (5). It is noteworthy, therefore, that all these categories have elements in common, especially in regard to the knowledge conveyed and required in both realities: high school content is objective and theoretical, and in the university, a reflective and practical knowledge institution, associated with the professional's graduation, therefore more significant for the subject.

At the same time, the perception of students is directly related to the attitude of the teacher/professor in the classroom and, consequently, the results show that teaching didacticism at school is more authoritarian and punitive, and the students have to obey usually. Due to this directive aspect from the teacher and the subject, the student is more likely to be dependent and restricted about seeking knowledge for personal purposes. On the other hand, in the university, the professor takes over the role of facilitator, valuing the encouragement of reflection, thinking, turning to the students the responsibility for their learning process and giving them the environment to be more autonomous; it requires more dedication to studies and management of other aspects of life, whether academic or personal.

Autonomy is promoted not only by the professor but by the university context in itself. The fact that the environment is broad invites the students to be the protagonists of their graduation process and also their personal growth, as they learn to cope with new demands and to conduct the management of adverse situations and the involvement in mature interpersonal relationships.

At the same time, it is observed that the perception of growth conditions is far distant from the affirmative policies. For the participants, these conditions would be offered by the university in both curricular and extracurricular aspects. In the curricular aspect, the interviewees highlight the level of excellence about the teaching at the university, the fact that the institution provides a theoretical apparatus that enables them to be professionals in their respective areas. Also, they consider growing conditions to be related to extracurricular activities such as research, monitoring, extension, etc.

\section{Conclusions}

In general, it can be observed, among the participant group, a positive perception of the university towards the fact that this is not only enabling professional growth, but also growth in the personal level, for the adversity and variety of context have generated an expansion of perception and apprehension of the world. However, it should not be disregarded that the students barely mentioned the affirmative policies offered by the institution, probably because of lack of information and support for the freshmen students. The university environment was, at first, considered potentially threatening for the college students; however, the subjects showed no signs of maladjustment, but positive expectations for the incoming years of graduation. 
This study contributes with information about the academic context and with a discussion of a thematic that has a relevant international repercussion, but is still incipient in the national literature.

Thus, it allows an overview on the specificities experienced by students that just left high school and entered to the university environment in relation to their transition and adaptation processes, allowing to research possible difficulties and needs that may contribute to the student's adaptation, such as institutional policies.

As limitation to this study, we consider the number of eight participants a small size sample. Although this factor, this study shows evidences of a qualitative research and shows analysis about the phenomenon from the speeches of the students, which is the goal of a qualitative study; we propose that other studies research the transition to college for recent high school graduates in order to corroborate and compare to the findings of this paper. Also, for future research, we suggest that studies approach emphatically the aspects of the growth conditions offered by the university, the perception of the offers and how the students have access to information about the opportunities. Also, we suggest that quantitative studies address the issue more broadly in an institution of higher education, allowing a general look at the transition and adaptation of recent high school graduates attending their first year of college.

\section{References}

Almeida, L. S. (2002). Factores de sucesso/insucesso no ensino superior. In Actas do Seminário Sucesso e Insucesso no ensino superior Português. Lisboa: Conselho Nacional de Educação, 103-119.

Almeida, L. S. (2007). Transição, adaptação acadêmica e êxito escolar no ensino superior. Revista Galego-Portuguesa de Psicoloxía e Educación, 15, 203-215.

Almeida, L. S., \& Cruz, J. F. A. (2010). Transição e Adaptação Académica: reflexões em torno dos alunos do $1^{\circ}$ ano da Universidade do Minho. In Ensino Superior em Mudança: Tensões e Possibilidades. UM. CIEd. Actas do Congresso Ibérico, Braga, Portugal.

Almeida, L. S., Soares, A. P., \& Ferreira, J. A. (2000). Transição e adaptação à Universidade: Apresentação do Questionário de Vivências Académicas. Psicologia, 19, 189-208.

Almeida, L. S., Soares, A. P., Guisande, A. A., \& Paisana, J. (2007). Rendimento académico no ensino superior: Estudo com alunos do $1^{\circ}$ ano. Revista Galego-Portuguesa de Psicoloxía e Educación, 14, 207-220.

Azevedo, A., \& Faria, L. (2004). Transição para o ensino superior: Estudo preliminar de um Questionário de Experiências de Transição Académica. Porto: Faculdade de Psicologia e de Ciências da Educação. http://repositorio-aberto.up.pt/bitstream/10216/15645/2/83171.pdf

Coulon, A. (2008). A condição de estudante: A entrada na vida universitária. Salvador: EDUFBA.

Igue, E. A., Bariani, I. C. D., \& Milanesi, P. V. B. (2008). Vivência acadêmica e expectativas de universitários ingressantes e concluintes. Psico-USF, 13, 155-164.

Machado, M. C. (2009) Vagas no ensino superior quadruplicam. Ministério da Educação. http://portal.mec.gov.br/

Pachane, G. G. (2003). A experiência universitária e sua contribuição ao desenvolvimento pessoal do aluno. In E. Mercuri, \& S. A. J. Polydoro, (Orgs.), Estudante universitário: Características e experiências de formação. Taubaté: Cabral.

Soares, A. B., Poubel, L. N., \& Mello, T. V. S. (2009). Habilidades sociais e adaptação acadêmica: Um estudo comparativo em instituições de ensino público e privado. Aletheia, 29, 27-42.

Soares, A. P. (2003). Transição e adaptação ao Ensino Superior: construção e validação de um modelo multidimensional de ajustamento de jovens ao contexto universitário. Dissertação de doutoramento. Braga, Portugal.

Teixeira, M. A. P., Castro, D. G., \& Piccolo, L. R. (2007). Adaptação à Universidade em Estudantes Universitários: Um estudo correlacional. Interação em Psicologia, 11, 211-220.

Teixeira, M. A. P., Dias, A. C. G., Wottrich, S. H., \& Oliveira, A. M. (2008). Adaptação à universidade em jovens calouros. Psicologia Escolar e Educacional, 12, 185-202. http://dx.doi.org/10.1590/S1413-85572008000100013 
Scientific Research Publishing (SCIRP) is one of the largest Open Access journal publishers. It is currently publishing more than 200 open access, online, peer-reviewed journals covering a wide range of academic disciplines. SCIRP serves the worldwide academic communities and contributes to the progress and application of science with its publication.

Other selected journals from SCIRP are listed as below. Submit your manuscript to us via either submit@scirp.org or Online Submission Portal.
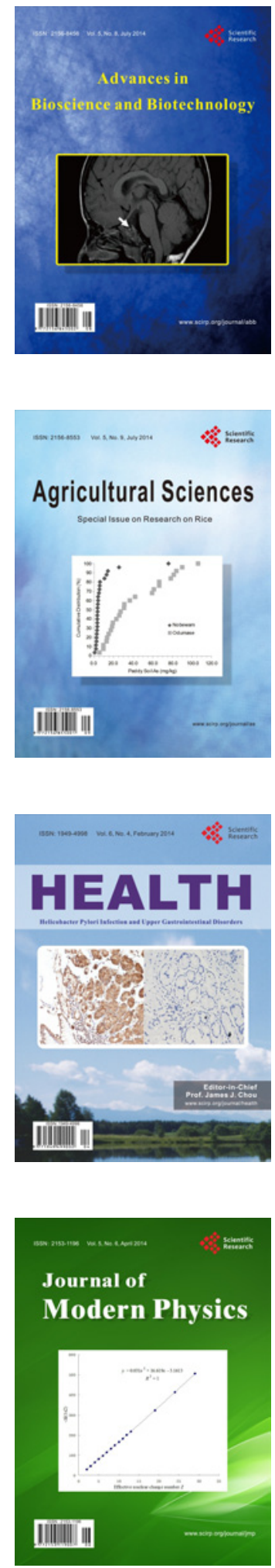
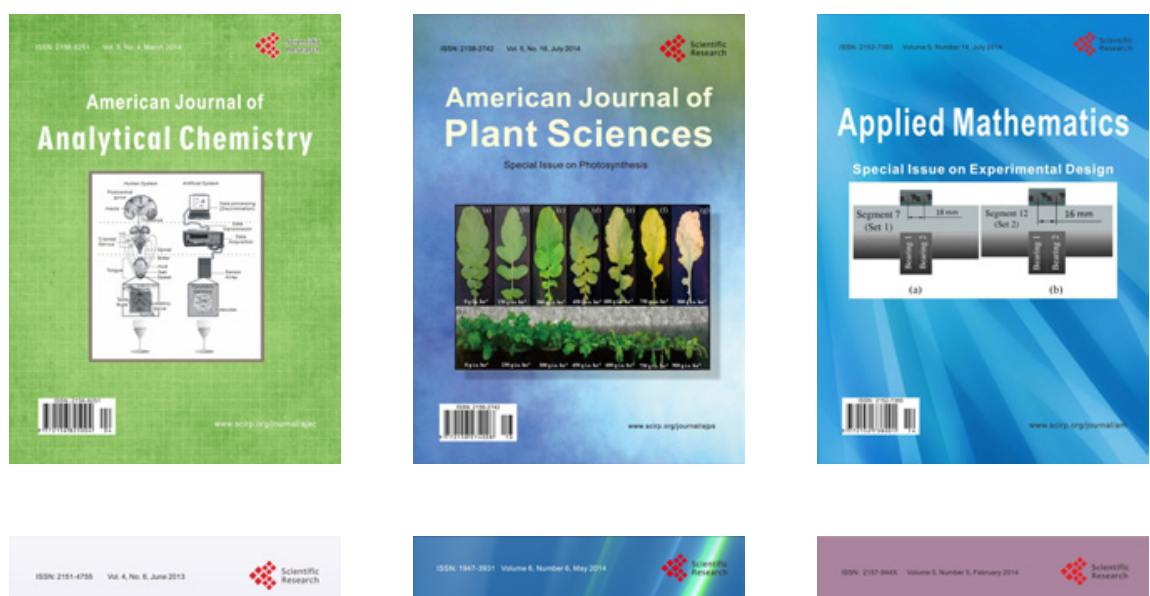

Creative Education
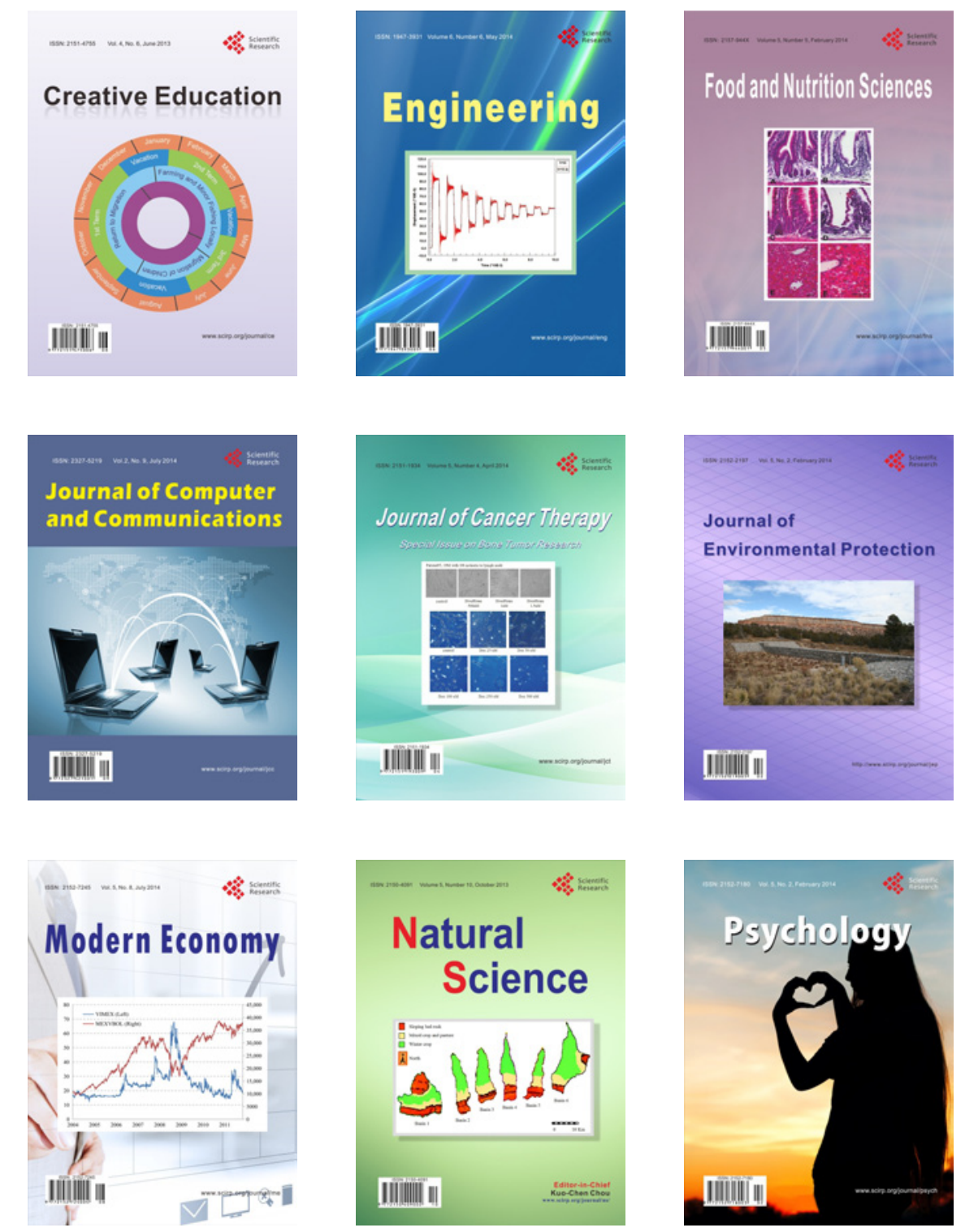